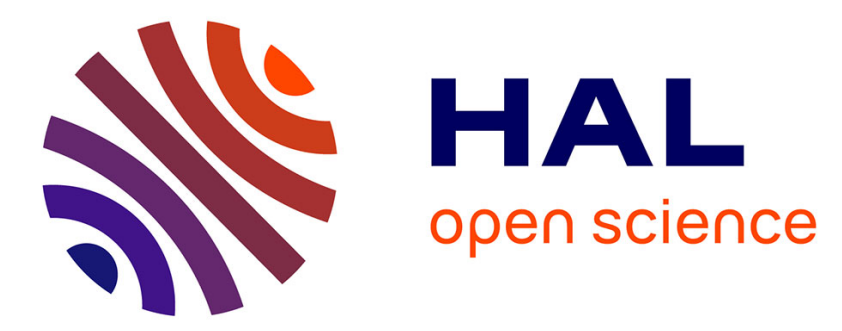

\title{
Differential gene expression in oyster exposed to sewage
}

Igor Dias Medeiros, Marília Nardelli Siebert, Guilherme de Toledo E Silva, Milton Osório Moraes, Maria Risoleta Freire Marques, Afonso Celso Dias Bainy

\section{- To cite this version:}

Igor Dias Medeiros, Marília Nardelli Siebert, Guilherme de Toledo E Silva, Milton Osório Moraes, Maria Risoleta Freire Marques, et al.. Differential gene expression in oyster exposed to sewage. Marine Environmental Research, 2008, 66 (1), pp.156. 10.1016/j.marenvres.2008.02.048 . hal-00563019

\section{HAL Id: hal-00563019 https://hal.science/hal-00563019}

Submitted on 4 Feb 2011

HAL is a multi-disciplinary open access archive for the deposit and dissemination of scientific research documents, whether they are published or not. The documents may come from teaching and research institutions in France or abroad, or from public or private research centers.
L'archive ouverte pluridisciplinaire HAL, est destinée au dépôt et à la diffusion de documents scientifiques de niveau recherche, publiés ou non, émanant des établissements d'enseignement et de recherche français ou étrangers, des laboratoires publics ou privés. 


\section{Accepted Manuscript}

Differential gene expression in oyster exposed to sewage

Igor Dias Medeiros, Marília Nardelli Siebert, Guilherme de Toledo e Silva, Milton Osório Moraes, Maria Risoleta Freire Marques, Afonso Celso Dias Bainy

PII:

S0141-1136(08)00075-5

DOI:

10.1016/j.marenvres.2008.02.048

Reference:

MERE 3221

To appear in:

Marine Environmental Research

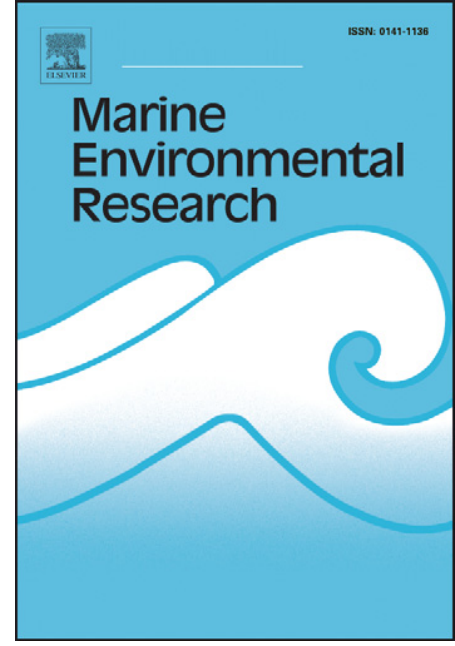

Please cite this article as: Medeiros, I.D., Siebert, 1.N., de Toledo e Silva, G., Moraes, M.O., Freire Marques, M.R., Dias Bainy, A.C., Differential gene expression in oyster exposed to sewage, Marine Environmental Research(2008), doi: 10.1016/j.marenvres.2008.02.048

This is a PDF file of an unedited manuscript that has been accepted for publication. As a service to our customers we are providing this early version of the manuscript. The manuscript will undergo copyediting, typesetting, and review of the resulting proof before it is published in its final form. Please note that during the production process errors may be discovered which could affect the content, and all legal disclaimers that apply to the journal pertain. 


\title{
Differential gene expression in oyster exposed to sewage
}

\author{
Igor Dias Medeiros ${ }^{\text {a,b }}$, Marília Nardelli Siebert ${ }^{\text {a }}$, Guilherme de Toledo e Silva ${ }^{\text {a }}$, \\ Milton Osório Moraes ${ }^{\mathrm{c}}$, Maria Risoleta Freire Marques ${ }^{\mathrm{a}}$, Afonso Celso Dias \\ Bainy ${ }^{a, *}$ \\ ${ }^{a}$ Departamento de Bioquímica, Centro de Ciências Biológicas, Campus Universitário, Universidade Federal de \\ Santa Catarina, Florianópolis, SC, Brazil 88040-900 \\ ${ }^{b}$ Laboratório de Ciências Marinhas, Universidade do Sul de Santa Catarina, Av. Colombo Sales, 89, Laguna, SC, \\ Brasil, $88790-000$ \\ ${ }^{c}$ Laboratório de Hanseníase, Fundação Oswaldo Cruz, Cruz, Instituto Oswaldo Cruz, Av. Brasil, 4365 \\ Manguinhos ,21045-900 - Rio de Janeiro, RJ - Brasil
}

\begin{abstract}
In order to investigate the influence of domestic sewage on the gene expression of Pacific oysters Crassostrea gigas, Suppression Subtractive Hybridization (SSH) method was employed. Oysters were sampled at a farming area and, after 10 days of acclimation in the laboratory, were exposed to untreated domestic sewage diluted $33 \%$ for $48 \mathrm{~h}$. Gills of male oysters were excised for total RNA extraction. mRNA was purified and the differential gene expression was analyzed by SSH. We obtained 61 cDNA sequences but only 15 were identified, which includes Fatty Acid Binding Protein, Multidrug Resistance Protein, Omega Glutathione S-Transferase,
\end{abstract}


cytochrome P450 isoform CYP356A1, among others. The identified genes are associated with different metabolic functions like biotransformation, membrane transport, aerobic metabolism and translational machinery, evidencing the potential toxic effects elicited by these effluents.

Keywords: Crassostrea gigas; SSH; Gene expression; Sewage; Biomarker; Monitoring.

*Corresponding author: Email address: bainy@mbox1.ufsc.br (A.C.D. Bainy)

Sewage discharges in marine and estuarine ecosystems are a common practice around the world. Besides the high input of organic matter, sewage may contain several kinds of persistent or non-persistent contaminants, such as pharmaceuticals, personal and home care products, surfactants, plasticizers, polycyclic aromatic hydrocarbons and trace metals, which are continuously delivered and its negative effects on the organisms must be considered (Petrovic et al., 2003). Bivalves are frequently employed in biomonitoring programs because they are filterfeeders, easy to collect and largely distributed. The areas of bivalve genomics and transcriptomics are emerging fields considering their application to aquaculture, fisheries and environmental sciences (Saavedra and Bachère, 2006). The aim of this study was to investigate differential gene expression in the Pacific oyster Crassostrea gigas after sewage exposure, under controlled laboratory conditions, in order to identify new potential biomarkers of exposure. For this purpose, we employed suppressive subtractive hybridization ( $\mathrm{SSH})$.

Pacific oysters (two years old) were supplied by the oyster culture facility from the Universidade Federal de Santa Catarina and transferred to the laboratory. Individuals were kept in two $45 \mathrm{~L}$ tanks $(\mathrm{n}=11)$ with aerated filtered marine water (salinity $24 \mathrm{ppt}$; temperature $24 \underline{ \pm} 2^{\circ} \mathrm{C}$ ) 
for a 10 days acclimation period. After that, one group of animals was exposed for $48 \mathrm{~h}$ to untreated domestic sewage, diluted $33 \%$. The sewage sample was collected at the influent duct of the downtown wastewater treatment plant (Florianópolis, SC, Brazil) after solid material grid removal. The light gray color as well as the physical and chemical parameters were characteristic of fresh untreated domestic sewage (BOD 360mg/L; COD 393mg/L; SS $148 \mathrm{mg} / \mathrm{L}$ ) (Katsoyiannis and Samara, 2007; Al-Shammiri, 2004). A control group was kept in a tank containing filtered marine water diluted similarly in charcoal-filtered freshwater. The water was changed daily and the organisms were fed with microalgae. Likewise, the oysters were monitored daily by visual inspection to determine that they were alive and opening their valves. After the exposure period, the oysters were sacrificed, their sex was identified and the gills were excised and kept in RNAlater (Ambion) at $-20^{\circ} \mathrm{C}$ until RNA extraction. Oyster gills from male organisms from exposed and control groups were pooled ( $n=5$, each group) and total RNA was extracted in TRIZOL (Invitrogen Life Technologies, Carlsbad, CA). PolyA mRNA was isolated using Oligotex mRNA Mini kit (Qiagen, Valencia, CA). Sample purity, mRNA concentration and integrity were checked at 260 and $280 \mathrm{~nm}$ and in $2 \%$ agarose gel electrophoresis. SSH was performed according to PCR Select cDNA Subtraction Kit (Clontech, Palo Alto, CA) and only the forward subtraction was performed, to identify up-regulated genes. Subtracted libraries were obtained from $2 \mathrm{~g}$ mRNA of pooled gills, respectively, from exposed and control oyster groups (control group cDNA was referred to as the driver and the exposed group cDNA as the tester). Secondary (nested) PCR-amplified subtracted cDNA populations were cloned into the pGEM-T Easy Vector System and transformed into JM-109 E. coli cells (Promega, Madison, WI). Plasmids were extracted and purified using Perfectprep Plasmid Mini kit (Eppendorf, Hamburg). Sixty-one clones were sequenced using ABI Prism Big Dye Terminator Cycle Sequencing kit 
(PE Applied Biosystems). Deduced protein sequences were subjected to homology search through the BLAST program (http://www.ncbi.nlm.nih.gov/BLAST/).

From the sixty-one cDNA sequences, 15 were identified (Table 1). The data showed that different pathways of the oyster metabolism were changed after sewage exposure. Biotransformation genes, such as the new cytochrome P450 subfamily CYP356A1 (Toledo-Silva, this volume), omega gluthatione S-transferase (GST-O) and multidrug resistance protein (MDR) were up-regulated in the gills of sewage exposed oysters. Besides these biomarkers of exposure, other genes belonging to the transporters family, translational machinery, aerobic metabolism, and nuclear proteins were also induced in the exposed group. One of the most redundant clones contained the cDNA of fatty acid binding protein $(F A B P)$. FABP are small cytosolic proteins (12 - $15 \mathrm{kDa}$ ) that bind non-covalently to hydrophobic ligands, mainly fatty acids. It has been suggested that the sub-type L-FABP, originally identified in vertebrate liver, is associated with xenobiotic uptake and metabolism (Velkov et al., 2005). FABP is also associated with increased fatty acid oxidation, which in turn, could provide energy required for protein synthesis and detoxification.

A subsequent study using semi-quantitative analysis showed that the expression of CYP356A1, GSTO, MDR, FABP and aminolevulinic acid synthase (ALAS) were induced by 1.9, 3.3, 3.3, 43.6 and 2.9-fold, respectively in the gills of oysters exposed to sewage (Medeiros et al., 2007).

The use of SSH in environmental studies allows the identification of multiple genes that are differentially expressed that can help to elucidate biochemical strategies of adaptation and survival used by mollusks exposed to toxic compounds in domestic sewage. The applicability of these genes as potential biomarkers is being investigated through field experiments before they can be adopted in environmental programs. 


\section{Acknowledgements}

This work was supported by the Brazilian Council for the Scientific and Technological Development (CNPQ), Grant n. 475995/2003-1. ACDB is recipient of the CNPQ productivity fellowship. The authors would like to thank Dr. Jaime Fernando Ferreira and Dr. Claudio Manoel Rodrigues de Melo for assistance during the experiment set up, and to the CASAN (Florianopolis Wastewater Treatment Plant).

\section{References}

Al-Shamiri, M. (2004). Desalination, 170, 1-13.

Katsoyiannis, A., and Samara, C. (2007). Journal of Hazardous Materials, 141, 614-621.

Medeiros I.D., Siebert, M.N., Toledo-Silva, G., Rodrigues, T.B., Marques, M.R.F., and Bainy, A.C.D. (2007). Submitted to Comparative Biochemistry and Phisiology.

Petrovic, M., Gonzalez, S., and Barceló, D. (2003). Trends in Analytical Chemistry, 22, 685 696.

Saavedra, C., and Bachère, E. (2006). Aquaculture, 256, 1-14.

Toledo-Silva, G., Siebert, M.N., Medeiros, I.D., Sincero, T.C.M., Moraes, M.O., Goldstone, J., et al. (2007). Marine Environmental Research, This issue.

Velkov, T., Chuang, S., Prankerd, R., Sakellaris, H., Porter, C.J.H., and Scanlon, M. (2005). Protein Expression and Purification, 44, 23-31. 
Table 1.

List of up-regulated genes in gills of oyster Crassostrea gigas exposed for $48 \mathrm{~h}$ to untreated domestic sewage

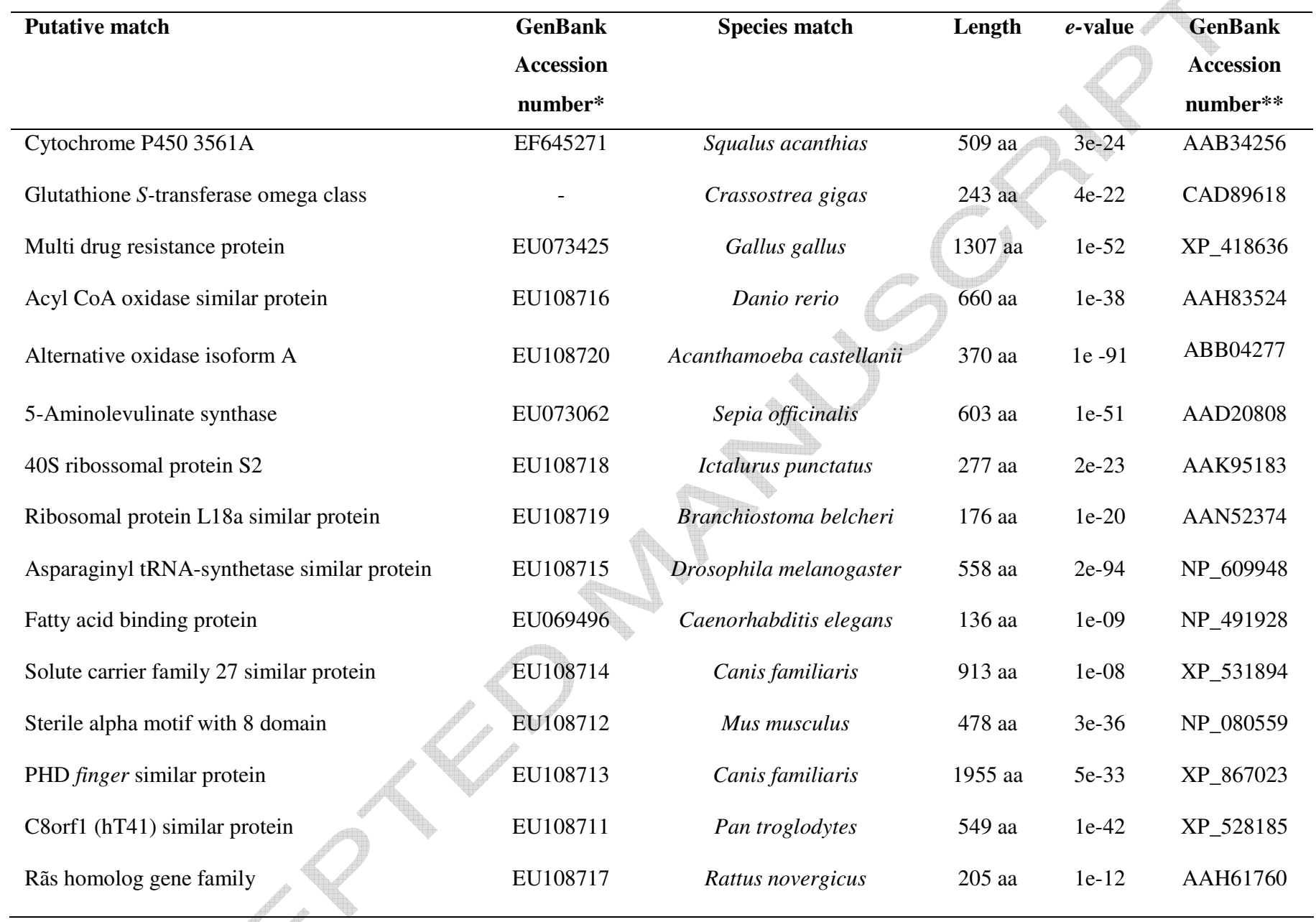

\footnotetext{
*Genbank access number deposited after this work. **Genbank access number of the closest
} match (e-value) obtained after blasting to National Center of Biotechnology Information 